\title{
PENERAPAN MODEL PROBLEM BASED LEARNING TERHADAP KEMAMPUAN BERPIKIR KRITIS PESERTA DIDIK PADA PEMBELAJARAN MATEMATIKA
}

\author{
Farihatun Nisa,Icha Arvyda Rhosaliana* \\ Universitas Islam Sultan Agung \\ rhosalianaicha@std.unissula.ac.id
}

Dikirim: 6 Januari 2020. Diterima: 30 Januari 2020. Dipublikasikan: 31 Januari 2020

\begin{abstract}
ABSTRAK
Penelitian ini bertujuan untuk mengetahui penerapan model problem based learning terhadap kemampuan berpikir kritis peserta didik pada pembelajaran matematika. Jenis penelitian yang digunakan adalah meta analisis dari penelitian yang telah dilakukan sebelumnya. Penelitian ini menggunakan metode deskriptif kuantitatif. Penelitian ini review tiga jurnal penelitian mengenai model problem based learning dalam mempengaruhi kemampuan berpikir kritis peserta didik pada pembelajaran matematika. Pengumpulan data dalam penelitian ini dilakukan dengan menelusuri jurnal melalui Google Scholar (Google Cendekia). Kata kunci yang digunakan untuk penelusuran jurnal adalah model problem based learning, kemampuan berpikir kritis, dan matematika. Dari beberapa jurnal penelitian model problem based learning terhadap kemampuan berpikir kritis dipilih tiga penelitian yang memenuhi kriteria untuk dianalisis lebih lanjut. Berdasarkan hasil analisis dari tiga jurnal penelitian disimpulkan bahwa penerapan model problem based learning pada masing-masing jurnal dapat diketahui terjadi peningkatan kemampuan berpikir kritis peserta didik pada mata pelajaran matematika yang ditandai dari peningkatan keberhasilan belajar peserta didik.
\end{abstract}

Kata kunci: model problem based learning, berpikir kritis, matematika

\begin{abstract}
This study aims to determine the application of problem based learning models to students' critical thinking skills in mathematics learning. This type of research is a meta-analysis of research that has been done before. This research uses quantitative descriptive methods. This study reviews three research journals about problem based learning models in influencing students' critical thinking skills in mathematics learning. Data collection in this research was carried out by searching journals through Google Scholar (Google Scholar). The keywords used for journal search are problem based learning models, critical thinking skills, and mathematics. From several research journals of problem based learning models on critical thinking skills, three studies were selected that met the criteria for further analysis. Based on the results of the analysis of three research journals it was concluded that the application of the problem based learning model in each journal can be seen an increase in students' critical thinking skills in mathematics which is marked by an increase in student learning success.
\end{abstract}

Keywords: problem based learning model, critical thinking, mathematics

\section{Pendahuluan}

Pendidikan merupakan sarana untuk meningkatkan kualitas bangsa, karena kemajuan suatu bangsa menjadi kebanggaan sendiri bagi negara tersebut. Pendidikan adalah usaha sadar dan terencana untuk mewujudkan suasana belajar dan proses pembelajaran agar peserta didik secara aktif mengembangkan potensi dirinya untuk memiliki kekuatan spiritual keagamaan, pengendalian diri, kepribadian, kecerdasan, akhlak mulia, serta keterampilan yang diperlukan dirinya, masyarakat, bangsa dan negara (Soekarnoputri, 2003).Pendidikan di Indonesia diharapkan mampu mengarahkan peserta didik mengembangkan potensi dalam dirinya. Potensi tersebut terukur dari kemampuan peserta didik sesuai dengan Undang-Undang Sistem Pendidikan Nasional Nomor 20 Tahun 2003. Peserta didik harus mampu memiliki kemampuan yang profesional sesuai bidang ilmu yang dipelajari. Kemampuan tersebut tidak lepas dari peran guru dalam proses kegiatan pembelajaran di sekolah. Peserta didik akan mendapatbanyak nilai-nilai kehidupan di sekolah yang akan terbawa dan tercermin terus dalam tindakan peserta didik di 
kehidupan bermasyarakat. Guru mempunyai peranan untuk ikut membina kepribadian peserta didik. Guru dalam proses kegiatan pembelajaran dituntut untuk tidak hanya menekankan aspek kognitif (pengetahuan) semata, tetapi aspek afektif (sikap) dan aspek psikomotor (keterampilan) peserta didik juga harus dikembangkan.

Titik berat kurikulum 2013 bertujuan untuk mendorong peserta didik atau siswa agar mampu lebih baik dalam melakukan observasi, bertanya, bernalar, dan mengomunikasikan (mempresentasikan) yang mereka peroleh atau mereka ketahui setelah menerima materi pembelajaran di sekolah(Anwar, 2013).Penilaian sikap dimasukkan dalam Kompetensi Inti (KI), yaitu KI 1 (nilai spiritual) dan KI 2 (nilai sosial). Sedangkan penilaian pengetahuan dan keterampilan terdapat pada KI 3 (nilai pengetahuan) dan KI 4 (nilai keterampilan). Nilai sikap pada KI 1 dan KI 2 diharapkan peserta didik tidak hanya mumpuni di bidang pengetahuan saja, tetapi memiliki sikap spiritual, sikap sosial, dan kerampilan yang baik. Selain menerapkan penilaian yang seimbang antara sikap, pengetahuan, dan keterampilan, Kurikulum 2013 juga menggunakan pendekatan sainstifik dalam proses kegiatan pembelajaran.Secara Istilah pengertian dari pendekatan saintifik adalah proses pembelajaran yang dirancang sedemikian rupa agar peserta didik secara aktif mengonstruk konsep, hukum atau prinsip melalui tahapan-tahapan mengamati (untuk mengidentifikasi atau menemukan masalah), merumuskan masalah, mengajukan atau merumuskan hipotesis, mengumpulkan data dengan berbagai teknik, meng-analisis data, menarik kesimpulan dan mengomunikasikan konsep, hukum atauprinsip yang "ditemukan"(Linda, 2017). Pembelajaran yang melibatkan pendekatan saintifikakan melibatkan keterampilan proses, seperti kegiatan pengamatan atau observasi yang dibutuhkan untuk pengajuan hipotesis atau pengumbulan data.Berdasarkan Peraturan Menteri Pendidikan dan Kebudayaan Nomor 65 Tahun 2013 tentang standar proses, model pembelajaran yang diutamakan dalam implementasi Kurikulum 2013 adalah model pembelajaran inkuiri (inquiry based learning), model pembelajaran discovery (discovery learning), model pembelajaran berbasis projek (project based learning), dan model pembelajaran berbasis permasalahan (problem based learning)(Linda, 2017).Sebagai seorang guru, kita harus mampu memilih dan mendesain model pembelajaran yang sesuai dengan tema dan kompetensi dasar yang harus dikuasai oleh peserta didik. Model pembelajaran yang kita pilih hendaknya disesuaikan dengan keadaan peserta didik, kemampuan peserta didik, sumber belajar, serta daya dukung yang dimiliki oleh guru dan sekolah.

Model pembelajaran yang masih monoton, dimana masih didominasi oleh guru membuat peserta didik merasa jenuh dan bosan. Saat guru menjelaskan materi pembelajaran, peserta didik tidak akan memperhatikan (peserta didik bermain sendiri atau membuat kegaduhan di kelas). Begitupun dengan pembelajaran Matematika, guru harus cermat mencari model pembelajaran yang tepat dan sesuai dengan peserta didik.Matematika merupakan mata pelajaran yang sangat bermanfaat bagi siswa. Mungkin saatini sebagai siswa mereka belum menyadari, namun mengingat pentingnya matematika maka diharapkan siswa antusias dalam pembelajaran(Ulia \& Sari, 2018).

Saat ini proses pembelajaran di kelas masih ditemukan guru yang memposisikan peserta didik sebagai objek belajar, bukan sebagai individu yang harus dikembangkan potensi yang dimilikinya. Hal ini dapat mematikan potensi peserta didik. Keadaan tersebut berakibat pesertadidikhanya mendengarkanguru di depan kelas, sehingga peserta didik mudah merasa bosan dengan materi yang diberikan.

Peserta didik kelas IV yang berada pada usia antara tujuh sampai dengan sebelas tahun berada pada tahap operasional konkret.Tahap oprasional konkret (concrete operational stage), yang berlangsung kira-kira dari usia 7hingga 11 tahun, merupakan tahap ketiga Piaget. Pada tahap ini anak-anak dapat melakukan operasi, dan penalaran logis menggantikan pemikiran intuitif sejauh pemikiran dapat diterapkan ke dalam contoh-contoh yang spesifik atau konkrit. Misalnya, pemikir oprasional konkrit tidak dapat membayangkan langkah-langkah yang diperlukan untuk menyelesaikan suatu persamaan aljabar, yang terlalu abstrak untuk dipikirkan pada tahap perkembangan ini(Ismail, 2019).

Problem based learning merupakan suatu model pembelajaran yang menantang peserta didik untuk belajar bekerja secara berkelompok untuk mencari solusi dari permasalahan dunia nyata. Dari permasalahan tersebut peserta didik dapat berpiki rkritis untuk menyelesaikan masalah yang ditemukan. 
Berdasarkan permasalahan yang dihadapi peserta didik, maka diperlukan suatu model pembelajaran yang tepat dalam mata pelajaran Matematika, yaitu dengan menggunakan model pembelajaran problem based learning. Dengan menggunakan model pembelajaran problem based learning diharapkan peserta didik dapat mempunyai kemampuan berpikir kritis pada mata pelajaran Matematika.Sehingga Penulis membuat judul "Penerapan Model Problem Based Learning Terhadap Kemampuan Berpikir Kritis Pada Pembelajaran Matematika" untuk merangkum, mereview, dan menganalisis data penelitian model pembelajaran problem based learning terhadap kemampuan berpikir kritis peserta didik pada pembelajaran matematika dari beberapa hasil penelitian yang sudah ada sebelumnya.

\section{Metode Penelitian}

Jenis penelitian ini menggunakan studi dokumen hasil penelitian-penelitian sebelumnya. Teknik pengumpulan data dalam penelitian ini, dengan menelusuri jurnal-jurnal di media elektronik internet. Penelusuran jurnal dilakukan melalui Google Scholar (Google Cendekia). Kata kunci yang digunakan untuk penelusuran jurnal adalah model problem based learning, kemampuan berpikir kritis, dan matematika.

Dari hasil penelusuran, dipilih tiga penelitian yang memenuhi criteria yaitu tersedianya data sebelum dan sesudah penelitian tentang penerapan model problem based learning terhadap kemampuan berpikir kritis peserta didik padapembelajaranmatematikadalambentukskor.Skor yang diperoleh kemudian dianalisis dengan mencari persentase. Teknik analisis yang digunakan dengan membandingkan selisih skor sebelum dan sesudah penelitian sebagai bukti adanya keberhasilan kemampuan berpikir kritis peserta didik.

\section{Hasil Penelitian dan Pembahasan}

Setelah melakukan penelusuran pada Google Scholar (Google Cendekia) dengan kata kunci model problem based learning, kemampuan berpikir kritis,dan matematika diperoleh hasil penelitian yang memenuhi kriteria, kemudian penulis memilih tiga penelitian. Tiga penelitian yang dipilih yaitu Brillian Rosy dan Triesninda Pahlevi (2015), Saiful Prayogi dan Muhammad Asy'ari (2013), dan Indri Anugraheni (2018). Berdasarkan tiga penelitian tersebut, beriku thasil analisis terkait penerapan model problem based learning terhadap kemampuan berpikir kritis peserta didik pada pembelajaran matematika:

Tabel 1. Penerapan Model Problem Based Learningt erhadap Kemampuan Berpikir Kritis Peserta Didik pada Pembelajaran Matematika

\begin{tabular}{|c|c|c|c|c|c|}
\hline \multicolumn{6}{|c|}{ Keberhasilan Kemampuan Berpikir Kritis } \\
\hline No. & Judul & Peneliti & $\begin{array}{c}\text { Semula } \\
(\%)\end{array}$ & $\begin{array}{l}\text { Sesudah } \\
(\%)\end{array}$ & $\begin{array}{c}\text { Grain } \\
(\%)\end{array}$ \\
\hline 1. & $\begin{array}{l}\text { Penerapan Problem Based Learning untuk } \\
\text { Meningkatkan Kemampuan Berpikir } \\
\text { Kritis dan Keterampilan Memecahkan } \\
\text { Masalah }\end{array}$ & $\begin{array}{l}\text { Brillian Rosy } \\
\text { dan Triesninda } \\
\text { Pahlevi (2015) }\end{array}$ & $79,42 \%$ & $82,29 \%$ & $2,87 \%$ \\
\hline 2. & $\begin{array}{l}\text { Implementasi Model PBL (Problem } \\
\text { Based Learning) untuk Meningkatkan } \\
\text { Hasil Belajar dan Kemampuan Berpikir } \\
\text { Kritis Siswa }\end{array}$ & $\begin{array}{l}\text { Saiful } \\
\text { Prayogidan } \\
\text { Muhammad } \\
\text { Asy'ari (2013) }\end{array}$ & $63,16 \%$ & $85 \%$ & $21,84 \%$ \\
\hline 3. & \begin{tabular}{|l} 
Meta Analisis Model Pembelajaran \\
Problem Based Learning dalam \\
Meningkatkan Keterampilan Berpikir \\
Kritis di Sekolah Dasar
\end{tabular} & $\begin{array}{l}\text { Indri } \\
\text { Anugraheni } \\
(2018)\end{array}$ & $43,6 \%$ & $58,33 \%$ & $12,73 \%$ \\
\hline \multicolumn{3}{|c|}{ Rata-rata Keberhasilan Kemampuan Berpikir Kritis } & $62,06 \%$ & $75,21 \%$ & $12,46 \%$ \\
\hline
\end{tabular}


Data yang diperoleh dari tiga penelitian di atas, menunjukkan bahwa model problem based learning dapat meningkatkan kemampuan berpikir kritis peserta didik. Keberhasilan kemampuan berpikir kritisdari yang terendah $2,87 \%$ sampai yang tertinggi $21,84 \%$, dengan rata-rata $12,46 \%$. Rata-rata keberhasilan kemampuan berpikir kritis sebelum penelitian adalah $62,06 \%$ dan setelah dilakukan penelitian dengan penerapan model problem based learning terjadi peningkatan 75,21\%.

Melalui pembelajaran berbasis masalah (problem based learning), peserta didik dapat 1) mengembangkan dan menyajikan hasil karyanya; 2) menganalisis dan mengevaluasi proses pemecahan masalah. Pada tahap mengembangkan dan menyajikan hasil karyanya, guru membantu peserta didik dalam menganalisis data yang telah terkumpul, kesesuaian data dengan masalah yang telah dirumuskan, kemudian dikelompokkan berdasarkan kategorinya. Peserta didik member argument terhadap jawaban pemecahan masalah. Karya bisa dibuat dalam bentuk laporan. Selanjutnya pada tahap menganalisis dan mengevaluasi proses pemecahan masalah, guru meminta peserta didik untuk merekonstruksi pemikiran dan aktivitas yang telah dilakukan selama proses kegiatan belajarnya. Guru dan peserta didik menganalisis dan mengevaluasi terhadap pemecahan masalah yang dipresentasikan setiap kelompok. Setelah selesai kegiatan pembelajaran, guru memberikan penguatan. Dengan demikian peserta didik memiliki konsep yang bulat tentang kompetensi dasar yang dipelajari.

Menurut (Rosy \& Pahlevi, 2015) berpikir kritis dalam penelitian ini adalah proses terorganisasi yang melibatkanaktivitas mental yang mencakup kemampuan merumuskan masalah, memberikan argumen, menyusun laporan, melakukan deduksi, induksi, evaluasi, memutuskan kemudian melaksanakan, dan berinteraksi dengan yang lain untuk memecahkan suatu masalah.Oleh sebab itu perlu diterapkan model problem based learning guna untuk merangsang berpikir tingkat tinggi dalam situasi yang berorientasi masalah. Sesuai dengan tujuan problem based learning yaitu membantu peserta didik mengembangkan kemampuan berpikir kritis, memecahkan masalah, dan keterampilan intelektual, maka peserta didik diharapkan dapat menggali dan menemukan sendiri dari pemecahan masalah yang diberikan guru sehingga dapatmemancing proses belajar mereka. Dalam konsepnya peserta didik bukan lagi obyek namun sebagai subyek belajar.

Hasil pengamatan padasiklus I ditemukan beberapa kekurangan yaitu (1) Siswa kurang memperhatikan penjelasan guru; (2) Siswa belum berani maju ke depan untuk mengerjakan contohcontoh soal yang diberikan guru dan untuk mengatasi kekurangan tersebut peneliti menyempurnakan model pembelajaran yang telah dilakukan pada siklus I yaitu dengan (1) Memotivasi siswa dengan memberikan pertanyaan- pertanyaan kontekstual sesuai dengan materi pada siklus II; (2) Memberikan reward kepada kelompok atau individu siswa yang bisa mengerjakan contoh soal yang diberikan guru(Prayogi \& Asy'ari, 2013).

Berdasarkan hasil-hasil penelitian diatas, dapat dilihat bahwa setiappenelitian yang dilakukan memperoleh hasil presentase peningkatan berpikir kritis yang berbeda-beda. Penulis menganalisis bahwa perbedaan hasil penelitian yang telah dilakukan oleh para peneliti tersebut disebabkan oleh faktor internal dan faktor eksternal. Faktor internal adalah faktor yang ada dalam diri peserta didik itu sendiri (seperti: kesehatan, minat, bakat, intelegensi, kondisi tubuh), sedangkan faktor eksternal yaitu faktor yang berasal dari luar diri peserta didik, yaitu faktor keluarga, lingkungan sekolah,dan lingkungan masyarakat (hubungan dengan tetangga). Latar belakang tempat penelitian juga mempengaruhi hasil penelitian yangdiperoleh karena berasal dari daerah yang berbeda. Tingkat kemampuan peserta didik juga berbeda sehingga hal itu juga berpengaruh terhadap hasil belajar yang diperoleh. Kondisi kesehatan peserta didik juga menjadi pengaruh, karena bisa saja saat peneliti mengambil data penelitian, kondisi kesehatan peserta didik sedang sakit sehingga tidak maksimal dalam mengerjakan tugas yang diberikan oleh guru. Penerapan kurikulum yang berbeda juga bisa menjadi dampak hasil belajar. Selain itu proses pembelajaran yang dilakukan oleh guru meskipun menggunakan jenis model yang sama, ada kemungkinan penerapannya mengalami perbedaan(Anugraheni, 2018).

Penjelasan dari tiga penelitian di atas, menunjukkan bahwa dengan penerapan problem based learning pada masing-masing jurnal penelitian dapat diketahui bahwa terjadi peningkatan kemampuan 
berpikir kritis pada pembelajaran matematika dan pembelajaran lainnya yang ditandai dari peningkatan keberhasilan belajar peserta didik.

\section{Simpulan dan Saran}

Simpulan

Implementasi kurikulum 2013 menekankan pada proses kegiatan belajar yang membutuhkan kemampuan berpikir kritis. Model pembelajaran problem based learning inilah, salah satu model pembelajaran yang dapat diandalkan. Sesuai dengan hasil tiga penelitian yang dipilih, menunjukkan keberhasilan kemampuan berpikir kritis peserta didik meningkat.

Saran

Penerapan model problem based learning terhadap kemampuan berpikir kritis peserta didik pada pembelajaran matematika membutuhkan waktu yang cukup lama. Peserta didik jika tidak diberikan pemahaman dan alasan yang tepat kenapa mereka harus berupaya untuk memecahkan masalah yang sedang dipelajari, maka mereka tidak akan belajar apa yang mereka ingin pelajari.

\section{DaftarPustaka}

Anugraheni, I. (2018). Meta Analisis Model Pembelajaran Problem Based Learning dalam Meningkatkan Keterampilan Berpikir Kritis di Sekolah Dasar. 14, 9-18.

Anwar, R. (2013). HAL-HAL YANG MENDASARI PENERAPAN KURIKULUM 2013. (45), 97-106.

Ismail. (2019). PERKEMBANGAN KOGNITIF PADA MASA PERTENGAHAN DAN AKHIR ANAKANAK ( Middle And Late Childhood ). 1(1), 15-22.

Linda, W. (2017). Keterampilan Menulis Kreatif Cerpen Menggunakan Media Audio Siswa Kelas Xii Sman 1 Kecamatan Payakumbuh. Bahastra, 37(1), 89. https://doi.org/10.26555/bahastra.v37i1.5641

Prayogi, S., \& Asy'ari, M. (2013). IMPLEMENTASI MODEL PBL (PROBLEM BASED LEARNING) UNTUK MENINGKATKAN HASIL BELAJAR DAN KEMAMPUAN BERPIKIR KRITIS SISWA. 1, 79-87.

Rosy, B., \& Pahlevi, T. (2015). PENERAPAN PROBLEM BASED LEARNING. 160-175.

Soekarnoputri, M. (2003). UU SISTEM PENDIDIKAN NASIONAL NOMOR 20 TAHUN 203. https://doi.org/10.16309/j.cnki.issn.1007-1776.2003.03.004

Ulia, N., \& Sari, Y. (2018). Pembelajaran Visual, Auditory dan Kinestetik Terhadap Keaktifan dan Pemahaman Konsep Matematika Siswa Sekolah Dasar. Al Ibtida: Jurnal Pendidikan Guru MI, 5(2), 175. https://doi.org/10.24235/al.ibtida.snj.v5i2.2890 